\title{
The Art of Making Animals Laugh Benjamin Rabier's Comic-Illustration of Les Fables de La Fontaine
}

\author{
Shu Hsuan Kuo
}

Published online: 3 April 2012

(C) The Author(s) 2012. This article is published with open access at Springerlink.com

\begin{abstract}
This article aims to explore book illustrations in the form of comic strips, and hence the nature of the format itself: how does it interpret the text, how does it narrate by itself and what is the significance of this "comic-illustration" in comparison to the traditional illustrations. The subject in question is the French artist Benjamin Rabier's illustrations of Les Fables de La Fontaine produced in 1906. As the term suggest, Rabier's "comic-illustration" stands between "comics" and "illustration". Unlike the cartoons with dialogue bubbles, his comics are more like coherent images beyond the text. This does not lead to pure decorations, however, because the images "narrate" the visual attractions in a pictorial way. In respect of illustration, the issue lies in the role of Rabier's work in the fable context. Deemed as an iconology in itself, the Fables contain a long list of illustrators. From the beginning of his illustration, Rabier displays an innovative viewpoint in his frontispiece by not showing any image of La Fontaine as most classical illustrators have done, but instead depicting a child narrating the stories to the characters. While the fable genre is considered as an art of making animals "talk", Rabier is making them "laugh" in this child's narration. Does this mean La Fontaine is interpreted as an easy and naïve reading, or is it a kind of sarcasm in disguise? The laughing animals therefore narrate another dimension in Rabier's comic-illustration.
\end{abstract}

Keywords Benjamin Rabier · Comics · Illustration · Fable $\cdot$ La Fontaine

Known for his design of the "la vache qui rit" (the laughing cow) trademark, Benjamin Rabier (1864-1939) was in his time a popular French artist, illustrator and author of comic books. Despite the diverse formats of his commercial work,

S. H. Kuo $(\bowtie)$

Pallas, Institute of Cultural Disciplines, Leiden University,

302a, P.N. van Eyckhof 3, 2311 BV Leiden, The Netherlands

e-mail: littlepau@gmail.com 
including newspapers, magazines, book illustrations and comic strips, Rabier developed a recognisable style for his cartoons and his characters. This is clearly visible in his Les Fables de La Fontaine, which includes 310 fables in coloured plates, published in 1906 by his publisher Jules Tallandier. ${ }^{1}$ Rabier's specific form of "comic illustration" appears to be different from contemporary mangas, comic books and graphic novels.

Taking Rabier's Les Fables de La Fontaine as an example, this article aims to explore the nature of book illustrations following the emergence of comic strips, and to re-examine Rabier's contribution to the history of fable illustrations. The article is therefore divided into two parts, the first dealing with the form of comic illustrations and the second with the contents of comic presentation. ${ }^{2}$ The questions of the first part include how comic illustrations interpret the text, how they create an independent narration, and what the significance of this form is when compared with other famous illustrations. The second part deals with the traditions and iconology of the fables of La Fontaine, as well as the comic nature of Rabier's laughing animals.

\section{Comic Illustration as a Form}

Although the term "comic illustration" has been loosely used in contemporary media, it does not in fact have a fixed definition, and usually refers to pictures in comic books only. However, the compound term precisely describes Rabier's precursory work, since many of his creations are positioned between "comics" and "illustrations", and hence fail to fit in either category. Before we investigate Rabier's work further, it is necessary to define the term more precisely.

The implication of this compound term is twofold. On the one hand, the "comic" aspect means not only the use of cartoon or comical pictures to illustrate text, which is not unusual in the caricature tradition of illustrations, but also adopting the physical format of comic strips. On the other hand, the meaning of "illustration" fits the conventional notion by literally illustrating and relying on the text plot; yet at the same time, it also presents another dimension beyond the text. In Rabier's example, and unlike in comic books or graphic novels which form a complete narration with dialogue balloons within picture frames, comic illustrations are best defined as coherent images accompanying or surrounding the text.

\footnotetext{
1 Apart from Les Fables de La Fontaine, Rabier also created other illustrations with a similar comic style, but it is in La Fontaine that Rabier displays a fully-developed and well-organised composition of comic illustration. His other illustrated books are either pure illustrations with comic characters or pure bandes dessinées.

2 Although it sounds dichotomous to discuss Rabier's work separately in terms of form and content, I regard it as a practical way to analyse his particular techniques and his role in the context of fable illustrations.
} 


\section{Time Narration}

The key feature of the format of comic illustrations is their narration in a time sequence. This is also the crucial difference between comic strips and other images in books. Unlike the single drawings of caricatures, comic strips narrate stories with images frame by frame; similarly, comic illustrations allow different phases of a fable story to take place on a single plate, instead of merely showing a certain point in time.

Take, for example, Rabier's illustrated plate of the well-known fable "The Cicada and the Ant" (Book I, 1; Fig. 1). The image story around the text begins at the top of the plate: here we see the cicada singing and playing its instrument in the spring field; simultaneously, on the right of the plate, the ant is working hard. The story goes on to the left side of the plate, where the cicada is sent away from the ant's door when the winter approaches; finally, it ends up dying on the snowcovered ground at the bottom right of the plate, which is an unusual scene to depict for this fable story. In this way, the plot of the story is implied by the coherent images around the text; however the images here are not as independent as in comic books where the texts are confined within the balloons or frames. This is the idea of comic illustration in Rabier's Fables.

The concept of presenting different visions on a single plate has already been hinted at in the history of fable illustrations. In an earlier illustration of the same fable story by François Chauveau (Fig. 2), ${ }^{3}$ for example, different dimensions were shown in one scene: in the foreground of Chauveau's illustration, the cicada and the ant are present in a realistic animal form, while the analogised human figures are simultaneously shown in the background. The solid existence of the closed house contrasts with the homeless people trying to keep warm around the campfire. Chauveau presented a double vision within a picture frame by making the juxtaposition between the animal signifier and the human signified. In Chauveau's illustration, the fable world coexists with reality; in this way he applied the moral of the animal story to the human world. ${ }^{4}$

Nevertheless, the presentation of Rabier's multiple time phases differs from Chauveau's multiple visions, because the images in the latter do not "narrate" the story in a time sequence but show a juxtaposition in space; while in a contemporary picture book by Jean-Noël Rochut, the illustrator shows a variation of time-narration in a single plate similar to Rabier's work. In his presentation of the same fable story, while the spring cicada is singing at the top of the tree on the left side of the plate, at the bottom of the tree, the same little creature is suffering in the winter storm. On

\footnotetext{
3 On 31 March 1668, Les Fables choisies mises en vers par M. de La Fontaine was published as six volumes containing 124 fables with 118 vignettes illustrated by François Chauveau. Chauveau himself was an acquaintance of La Fontaine, and his illustrations bear the recognisable clarity and directness of the essence of the fables which form the successive iconology of Fontainian illustrations (Gréverand 2002).

4 This interpretation is based on Collinet's introduction to his Pléiade edition of La Fontaine's fables (Collinet 1991). In fact, this analogy to the human world became so conventional that it reappeared frequently in later illustrations, for instance in Doré's famous image where the cicada is in fact depicted as a Gypsy woman.
} 


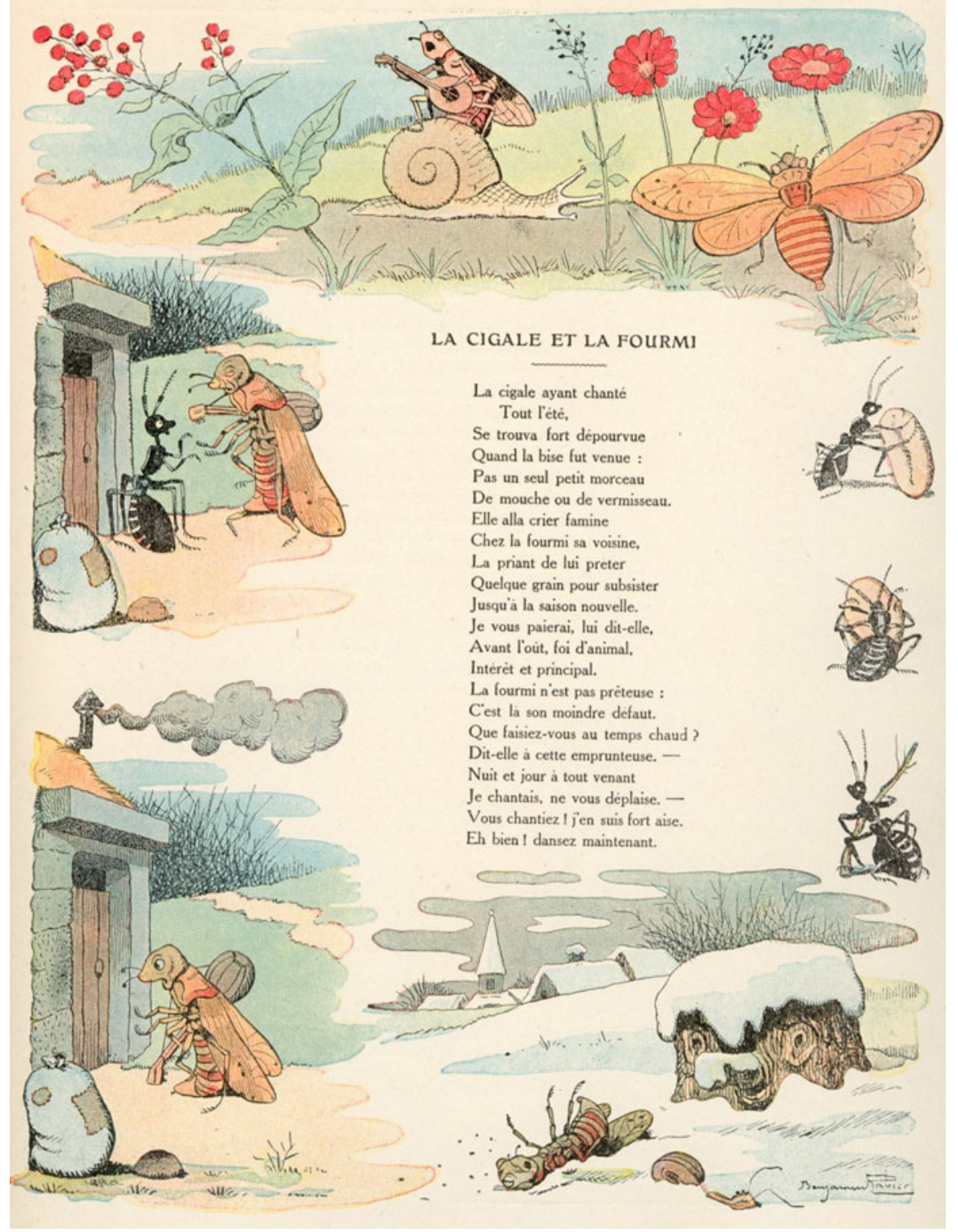

Fig. 1 Rabier, Benjamin, illustrated plate for "The Cicada and the Ant", Les Fables de La Fontaine, 1906

the back of the tree opposite, we see the frozen cicada asking for help from the ant. Therefore, all the subjects are displayed in a united space in which the plate narrates the story in three different time phases simultaneously.

It is significant to point out that the approach of Rabier and other artists with a similar style is important for another reason. In the conventional concept, literature 


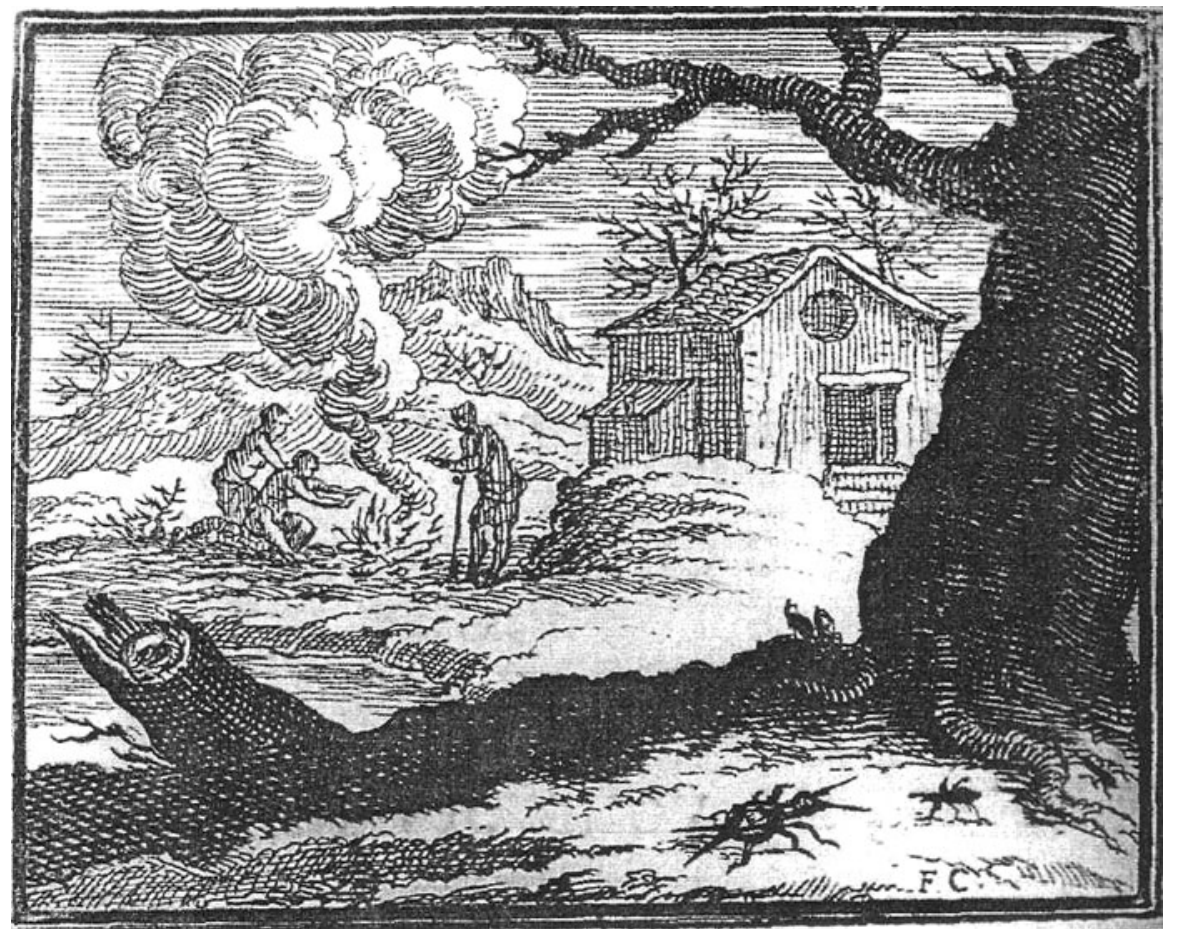

Fig. 2 François Chauveau, illustration of "The Cicada and the Ant", 1668

is viewed as the art of time while images are referred to as the art of space. However, since multiple time phases are allowed in Rabier's comic illustrations, the boundary between the temporal and spatial arts is diluted. Moreover, the relationship between words and images also implies a crossover from classical book illustrations to the contemporary form of comic books.

\section{Word-Image Relationship}

The specific relationship between words and images can be recognised in another feature in Rabier's comic illustrations. At first glance, his coloured plates resemble the decorative pages in works by Walter Crane (1845-1915); however, there is a fundamental difference between the two artists. In Crane's picture book Baby's Own Aesop (1887), it is the image that plays a dominant role, rather than the text, so that the hand-written typology of the text can actually be seen as part of the picture. Building on Crane's art-nouveau style of ornamenting books, Rabier chose to present both words and images in a more equal way in his comic illustrations.

Although in Rabier's illustrations for the Fables, it seems that words and images are highly integrated on the colour plate, as a matter of fact, they are separated by the picture frames and narrating stories respectively. His images are chosen not 
according to their importance in the text, but according to their visual attractiveness, which might not be closely related to the text, or may even go entirely unmentioned. In other words, if the artist found certain pictorial elements pleasing to the eye and appropriate for the illustrations, he would use these elements as a repeated decoration around the text. These elements therefore form another pictorial rhythm beyond the text itself, and it is not consequently always easy to understand the original plot simply by looking at those images. Rabier's comic illustrations, as a result, are not merely the support for text but a separate creation in and of themselves.

A typical example can be found in Rabier's illustrated plate for "The Fortuneteller" (Book VII, 16; Fig. 3), where the pictures seem to play freely with the text. Less well-known to the public, this fable talks about fate and human absurdity. In Rablier's plates, a number of framed vignettes follow the general plot of the original story, but the artist turns the spotlight on small animal characters which never show up in the text. In the vignettes at the end of the story-plate, a cat, an owl and the cards used by the fortune-teller to play tricks are adorned in framed emblems; beneath the last emblem, there is a rat posing as if reading human fate from the card, so as to make a strong ironic reference to the fortune-teller, who could not read but blabbed with her customers all her life. In this way, these pictorial elements present a story related to, but also independent from, the original text. The comic illustration hence opens up another dimension in which it provides a narrative in its own time and space.

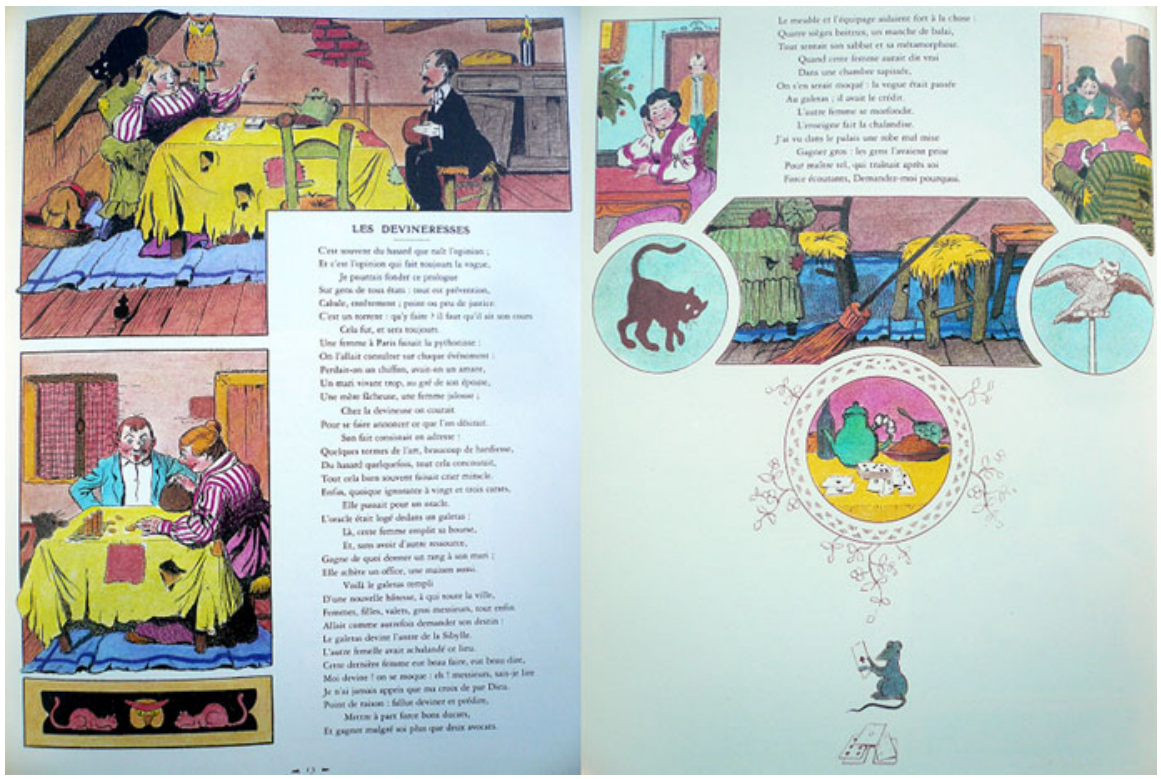

Fig. 3 Rabier, Benjamin, illustrated plate for "The Fortune-teller", Les Fables de La Fontaine, 1906 


\section{The Comic Presentation}

Rabier's illustrations of the Fables de La Fontaine distinguish themselves from his other illustration work. Unlike other comic stories he created or retold, the fable is a genre with a long tradition of depiction. Since it is seen as an iconology in itself, the images created by La Fontaine's illustrators differ tremendously in style according to their views on the fable world. Therefore, when he decided to produce the fable illustrations, Rabier was facing questions that many previous illustrators had encountered: how to break through the stereotypes set by François Chauveau's first illustrated edition of the Fables de La Fontaine, how to visualise those single plots with or without simple actions or plain dialogues in fables, and how to define the role of both the fable and its illustrator. In addition to these questions, if we are to attempt to evaluate Rabier's fable illustrations appropriately, it is important to investigate further questions: how does Rabier fit within the context of fable illustrations, and how does he bring a new contribution to the conventions of illustration.

The essence of Rabier's comic illustrations lies not only in the form of comic strips, but also in his caricature presentation. His laughing animals with human expressions are the marks of his artistic signature. At first sight, his laughing animals in the Fables seem to be the product of cartoon expressions, but in the context of fable illustrations, we find that Rabier's laughing animals actually allow for another interpretation of the relationship between humans and animals in the world of talking animals.

\section{Fables in Context: The Art of Making Animals Talk}

In a world where animals talk like human beings, it is interesting to see how fable illustrators visualise the idea of an imaginary world. Among the numerous illustrations of the Fables de La Fontaine, there are two major concepts for representing the fable world: in one view, one can see fables as an artificial creation in which the poet and the readers remain distant from the characters, while in the other view, one sees the fables as a link between Nature and the human world. ${ }^{5}$

Grandville's frontispiece ${ }^{6}$ is a typical example of the former. It reflects all the traits of a traditional portrait of La Fontaine: in a shrine-like composition, the bust of the classic poet La Fontaine is adorned on a structure made of fable animals and humans as architectural elements, including an artificial fountain-a playful allusion to the poet's name-in the lower background. Focusing on the artificial idea of the fable, this image testifies that La Fontaine is viewed as the creator of an imaginative and constructed world, which is nevertheless supposed to co-exist with the natural one. The Greek bust, the fountain, and the unrealistic gathering of fable animals together contribute to the conventional understanding of Les Fables de La Fontaine as a serious classic.

\footnotetext{
5 Here I adopt K. H. Powell's classification of fable illustrations (Powell 1996).

6 Jean-Ignace-Isidore Gérard, pseudonym J. J. Grandville, is a French caricaturist and book illustrator. His illustrated version of the Fables de La Fontaine was first published in 1838.
} 
On the other hand, there are many illustrators who view La Fontaine as a bridge or a communicator between the human and the natural world. In Cochin's frontispiece, for example, the role of "Nature" has overcome that of artifice. In a realistic forest environment, the images of both La Fontaine and the animals no longer appear as artificial objects, but as lively and personalised creatures. With the ability of communicating with animals, La Fontaine is shown here as an intimate friend of the animal characters who are able to "talk" and listen to him. Cham's caricatural title page goes even further in this respect since he gives up the representation of Nature altogether, and presents La Fontaine as a wild animals' language teacher in a human classroom, instructing the animals in "the art of talking" (l'art de faire parler). The ability to "dialogue" has been seen as evidence of suspended disbelief in the Fables, a determining element that separates imagination and reality. With the art of making animals talk, the world of the Fables satirises the human world on the one hand, while on the other hand constructing a new self-sufficient world. ${ }^{7}$

No matter how diverse the interpretations are, the image of La Fontaine himself is rarely omitted from the frontispieces of classical illustrators. However, the ultimate role of an omniscient author was overturned by artist-illustrators in the nineteenth century. With the rise of livres d'artistes, painters have striven for the individual expression of images other than the subordination of the poet/text. Therefore, coming back to Benjamin Rabier's frontispiece (Fig. 4), we find a familiar scene of communicating and "talking" to the animals, but instead of the figure of the poet-lecturer, a child has taken over the role of reciting the fables to these animals with their comic faces. The world of fables no longer belongs to adult writers or critics, but is constructed by, or returned to the pure imagination of a child-reader. It is the return to infancy that underlines and enlightens this piece.

Moreover, as mentioned above, one can recognise Rabier by the jubilant expressions of his characters. His frontispiece for the Fables is lit up by the laughing faces of the characters. If we place Rabier's work in the context of fable illustrations, we find a reasonable transmission: what Rabier has done here is no longer to make the animals "talk", but to make them "laugh". In this child's narration, the "dialogue" has been transcended into "laughter". In addition to his own artistic style, Rabier's laughing characters now surprisingly also fit into the dimension of fable illustrations. However, the next question is what makes the significance of these laughing animals. Does this mean that Les Fables de La Fontaine is to be interpreted as an easy and naïve children's book, or is this in fact a form of sarcasm in disguise? ${ }^{8}$

\footnotetext{
${ }^{7}$ In her article, Powell demonstrates many other examples of the relationship between La Fontaine and his illustrators through the presentation of different frontispieces (Powell 1996).

${ }^{8}$ We can compare Rabier's frontispiece with Marc Chagall's later works (1952). Instead of showing conversations between animals and the poet (or children or any other human beings), these two images from two volumes of the Fables display conversations between the animals themselves. The piece for volume 1 indicates the cunning and sarcastic dialogues between "The Crow and the Fox", and the one for volume 2 depicts the emotional and self-indulging dialogues between the "Two Pigeons". Essentially, with or without references to the human world, the fable world is a realm dedicated to talking animals. Chagall obviously tries to retreat from the adult world back to the purely animal world untainted by moral interpretations.
} 


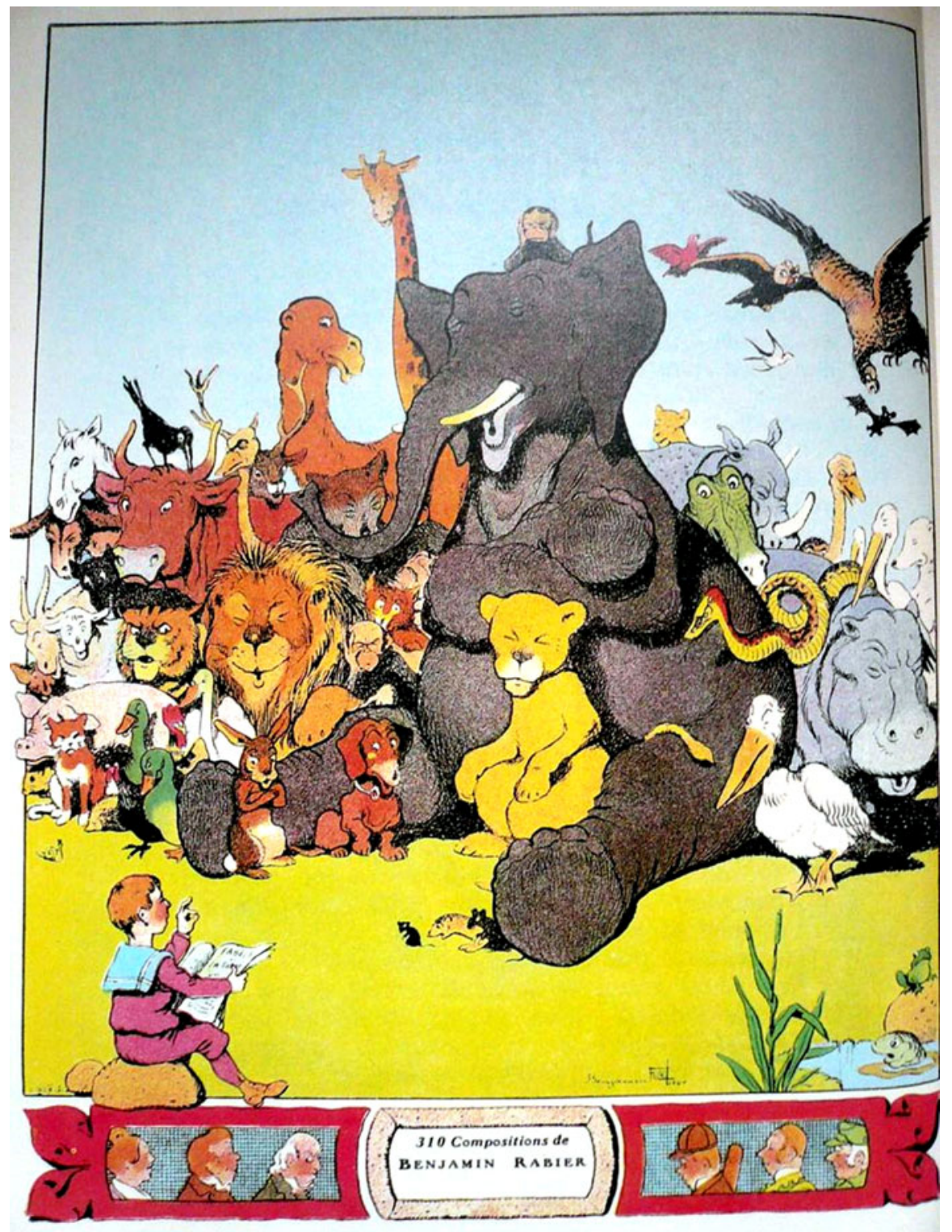

Fig. 4 Rabier, Benjamin, frontispiece of Les Fables de La Fontaine, 1906

Comic Essence: The Art of Making Animals Laugh

Despite their modern appearance, Rabier's comic illustrations can be traced to the French and English traditions of fable images, which are a combination of delicate, emblematic images and humorous, transformed caricatures. The laughing essence finds its roots in popular caricatures, either commercial or political. 
In fact, in his Les Fables de La Fontaine: quatre siècles d'illustration, Bassy classifies the traditions of fable illustrations into four categories: French, Italian, Flemish and English. The French tradition is largely influenced by the style of miniatures; therefore, the illustrations usually appear as delicate and well-organised emblems, as for example in the work of Chauveau and Oudry. The Italian tradition is based on mythological themes dating from the Renaissance and hence contains grand style and dramatic figure gestures. The Flemish tradition, in the manner of Brueghel, is distinguished by its rural atmosphere in which the legend stories are often presented in a solid and realistic way. Lastly, not unfamiliar with the tradition of caricature, the English style is dominated by burlesque or comic appearances (Bassy 1986). Consequently, the styles of fable illustrations can range from plain and straightforward illustrations, through the delicate and the grand, to the humorous and the satirical. We find that the work of illustrators from later generations still fits in with these traditions, or at least a combination of them.

The satirical tradition of Fables illustrations continued in the nineteenth century, when rich images appeared in fable stories. ${ }^{9}$ Applied in various discourses, many of these "children's stories" were presented as images of social criticism. Grandville's illustration for "The Fox and the Grapes" (Fig. 5) provides an example of doublesatire in the picture. First, in the foreground, animal characters dressed up in costumes personalise human society, hence the representation of this well-known fable: the gentlemen are lusting after the ladies as the fox lusts after the unreachable grapes; the animals' disguises here deepen the absurdity of the so-called "sophistication" of human society. Secondly, on the right side in the background, a real animal fox longing for the fruits embodies the natural world in the fable. As a consequence, human society itself is mocked and imitated by those "humanised" animals, whom are in turn mocked by the "natural" fox in the second sense. With this elaborate device, the social satire is sharply revealed through this caricature.

Shedding social and political implications, the comic tradition still retains its humorous appearance. The fable world becomes a playground in which men, animals and gods are burlesqued and laughed at, thus forming a comedy theatre in which all the characters perform in an exaggerated way. Oudry's illustration ${ }^{10}$ for "The Cicada and the Ant" again serves as a good testimony for the comic/theatrical essence in the Fables. By placing the two main characters on a theatre-like drapery, Oudry presents a stage-like space separated from the natural world but also integrated into it. The line between the real and the virtual can be vague and suspended at this moment.

\footnotetext{
9 We can take Honoré Daumier's work as an example of the caricatural presentation of fable subjects. Daumier once published a caricature of "La Cigale" in Le Charivari. Siding with Doré's analogy, Daumier makes the figure of the cicada refer to the wandering performers in contemporary society and condemns them as one of the sources of social problems in the acrid comment below the image: "we pay for not listening to them." ("On paie pour ne pas l'entendre." Le Charivari, 1837).

10 Jean-Baptiste Oudry (1686-1755) was a French Rococo-style painter and engraver. Known for his naturalistic paintings, Oudry amused himself by drawing 276 sketches for the Fables of La Fontaine during 1729-1735, and later on Charles-Nicolas Cochin undertook the responsibility of engraving these plates for him.
} 


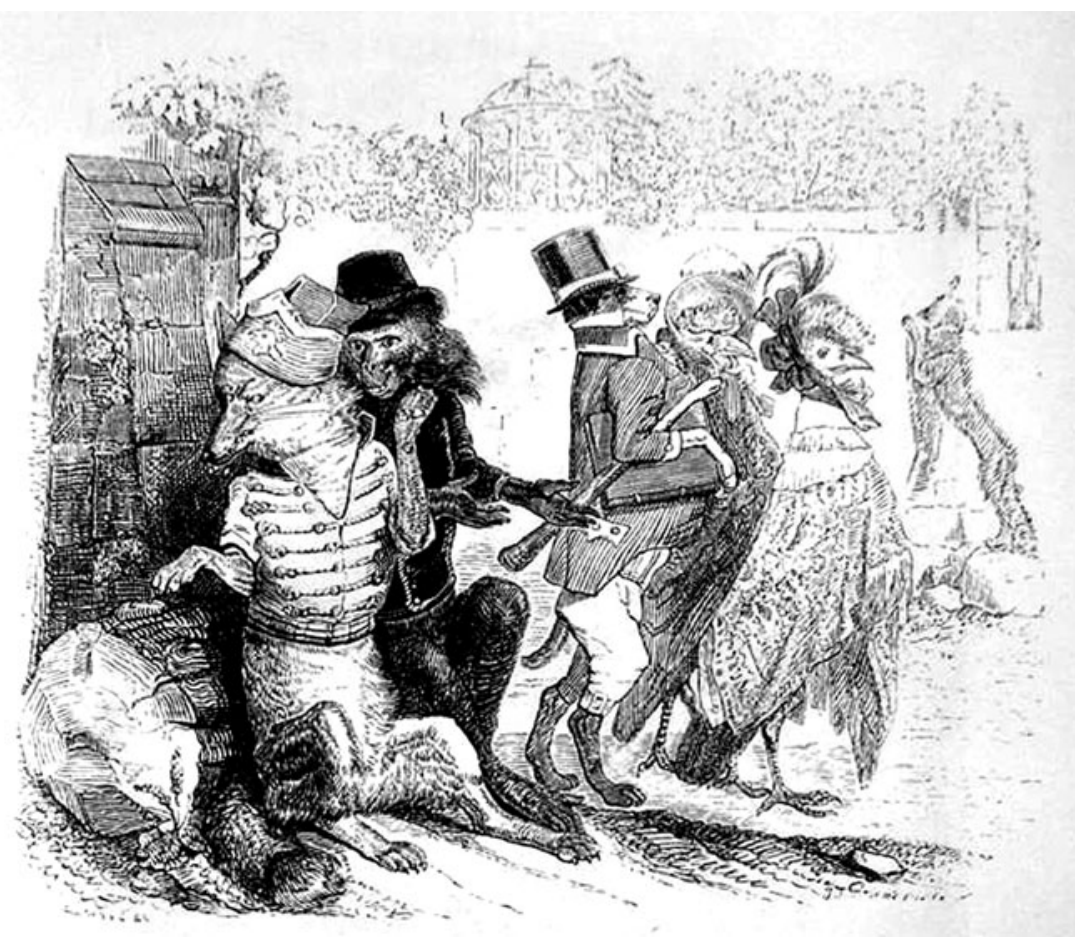

Fig. 5 J. J. Grandville, illustration of "The Fox and the Grapes “, 1841

One of the best examples of these theatrics can be found in Gustave Moreau's ${ }^{11}$ rather intriguing frontispiece. Following Moreau's own context of mysterious subjects, this image displays a figure seemingly unrelated to fable stories: a woman in Oriental costume leaning on a hippogriff, one of the motifs Moreau often applied to his paintings. This is the female personification of the "Fable" (the title word of Fable appears beside her head), who is holding a comedy mask and a whisk in her hand. The title of this perplexing image "Allegory of Fable" hints at the way Moreau sees the nature of fables: didactic morals functioning in comic disguises.

Therefore, if we re-examine Rabier's laughing animals, this comedy mask sheds a different light on "laughter" itself. The expression of "laughter" belongs to human beings only; for sure this is not a natural depiction of animals. Thus by representing this exaggerated/transformed laughter on the animals' faces, what Rabier has done is in a sense put a comedy mask on the animal characters. As a

\footnotetext{
11 Gustave Moreau (1826-1898) the Symbolist painter was originally commissioned to produce watercolours for the Fables of La Fontaine by his patron Antoni Roux for an edition including other works by major illustrators of the day, such as Doré, Lami, Baudry, Derôme, Raffaelli and so on. In 1881, nearly 150 watercolours were exhibited at the Cercle des Aquarellistes, held at the Galerie Durand-Ruel. In recognition of Moreau's outstanding work, Roux decided to commission Moreau to illustrate the whole oeuvre. However Roux's Fables proposal was never published; Moreau's watercolours today remain in private hands. See Calder, Andrew, 'Conversation and Commonplace', The Fables of La Fontaine, Genève: Librairie Droz S. A., (2001, pp. 105-115).
} 
result, when we view his frontispiece from this perspective, the laughing animal is no longer the product of a child's naïve reading of fable stories, but has become part of the artificial costumes from an adult's sophisticated point of view.

Throughout the history of festival aesthetics, laughter has played a crucial role in the performance of comedy. As in a theatre or a circus where, according to Baudelaire, laughter is a shocking effect caused by the loss of our emotional balance as a result of seeing something funny or extraordinary (Baudelaire 1956). Through laughter, we are able to see the sharp truth behind the theatre.

Rabier's illustrated plate for the fable story "The Bear and the Amateur Gardener" (Fig. 6) serves as a clear example of the power of laughter. When the bear and the human gardener become friends, they love each other in their own ways which result in tragedy: not knowing that human beings are much weaker than bears, the bear throws a rock on the sleeping man's face in order to kill the bee on his nose and of course, the man dies. This sad story of the inability to understand or communicate with the one you care about and love is depicted as a joyous comedy in Rabier's plates. Again, the vignettes narrate the story in a pictorial manner; the bear, the bee and the fatal rock are adorned in the emblems. The ending with the laughing face of the bear seems extremely ironic in view of the tragic line of the story.

Moreover, when we put "The Bear and the Amateur Gardener" in the context of communication between nature and animals, there emerges another interpretation of this unusual story. The laughing essence of Rabier's illustrated plate seems to hint at the vain attempt at communication; we are unable to understand those we love in the

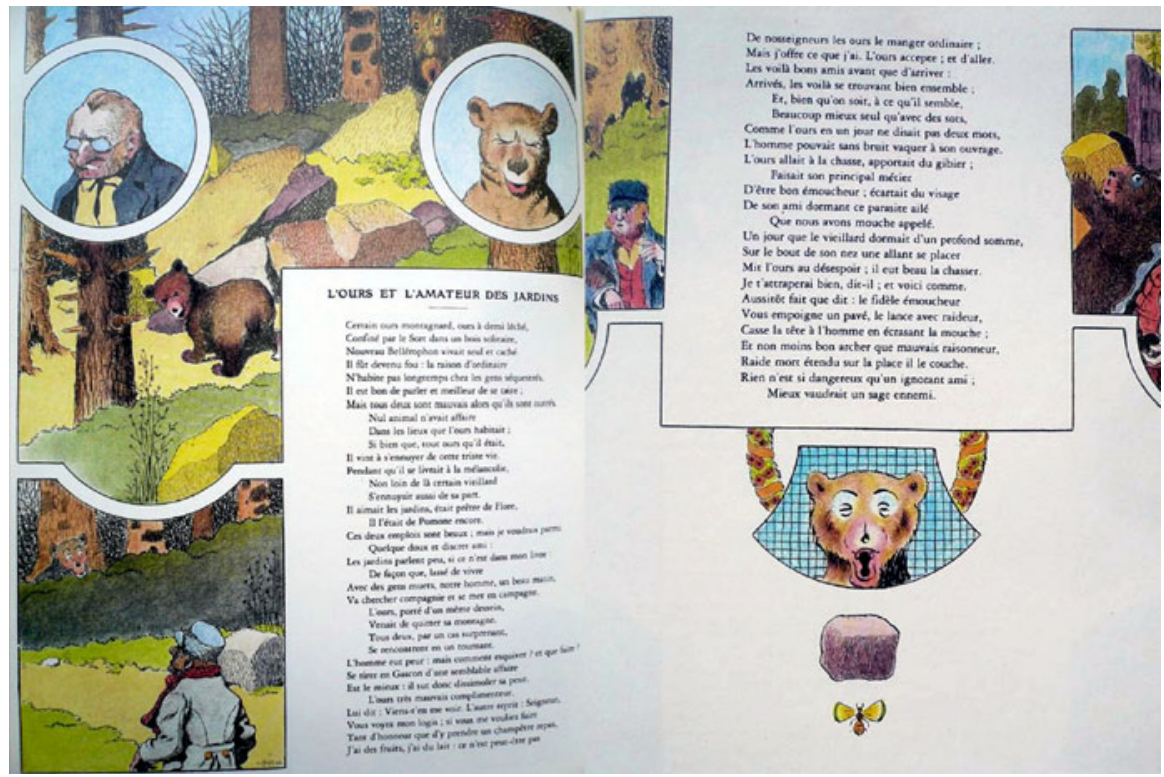

Fig. 6 Rabier, Benjamin, illustrated plate for "The Bear and the Amateur Gardener", Les Fables de La Fontaine, 1906 
same way that we can never thoroughly communicate with animals. In the end, the entire fable world, no matter how realistic, is a sophisticated theatre for mocking humans.

From making animals talk to making them laugh, from dialogue to laughter, Rabier's comic illustration brings out the ironic essence of the Fables through its pleasant form with the best narration possibilities. Rabier's Fables de La Fontaine on the one hand relates this new form of visualisation to the comic tradition, while on the other hand, his comic illustrations are elevated from a mere children's book to the tradition of classical book illustrations.

Open Access This article is distributed under the terms of the Creative Commons Attribution License which permits any use, distribution, and reproduction in any medium, provided the original author(s) and the source are credited.

\section{References}

Bassy, A.-M. (1986). Les Fables de La Fontaine: quatre siècles d'illustration. Paris: Éditions Promodis. Baudelaire, C. (1956). The essence of laughter. In The essence of laughter: And other essays, journals and letters. Northwestern University Press.

Calder, A. (2001). The Fables of La Fontaine: Wisdom brought down to earth. Genève: Librairie Droz S.A.

Collinet, J. P. (Ed.) (1991) Oeuvres complètes de Jean de La Fontaine: Fables et Contes, Gallimard.

Gréverand, G. (2002). Illustrations et illustrateurs, in La Fontaine et les artistes. Tournai: La Renaissance du Livre.

Powell, K. H. (1996). The art of making animals talk: Constructions of nature and culture in illustrations of the Fables of La Fontaine, Word \& Image, 12(3), 251-272. 